УДК 616.43:92 ЕФИМОВ

\section{АНДРЕЙ СЕМЕНОВИЧ ЕФИМОВ}

\section{(к 80-летию со дня рождения)}

10 ноября 2008 г. исполнилось 80 лет со дня рождения и 61 год трудовой деятельности академик: НАН и АМН Украины, Российской $\mathrm{AMH}$, заслуженного деятеля науки и техники $\mathrm{У}_{\mathrm{K}}$ раины, лауреата Государственной премии Украины, доктора медицинских наук, профессора, руконодителя отдела диабетологии, заместителя директора по клинике ГУ Институт эндокринологии и обмена вешеств им. В. П. Комиссаренко АМН УКраины Андрея Семеновича Ефимова.

Более 50 лет А. С. Ефимов отдал научной, научно-клинической, организашионной и преподавательской деятельности и внес весомый вклад в развитие отечественной и мировой эндокринологии, в частности диабетологии и тиреоидологии

А. С. Ефимов родился в с. Зиновьевка Саратовской области РФ. Научную работу начал будучи студентом Горьковского мединститута, исследуя в эксперименте аллоксановый диабет и гипертонию. После успешного окончания института в 1952 г. был оставлен в клинической ординатуре при этом институте.

После защиты кандидатской диссертации в 1955 г., посвященной психотерапевтическим методам лечения гипертонии и коронарных аниоспазмов, А. С. Ефимов был направлен на работу главным терапевтом медико-санитарной части одной из новостроек Сибири (Красноярск-26). Там же под его руководством и с его участием проводилось эпидемиологическое исследование размеров зобной эндемии в различных регионах Сибири. Было установлено, что повышенное содержание в почве и воде фтора и кальция способствует развитию зоба вследствие ศодного дефицита. Полученные результаты легли в основу метода массовой йодной профилактики, внедренного в ряде неблагоприятных в отношении развития зоба регионов Сибири.

После избрания в 1958 г. ассистентом кафедры терапии Горьковского мединститута А. С. Ефимов проводит хлинические и экспериментальные исследования нарушений нейрогормональной регулячии при развитии зобной болезни, обосновывает применение нейротропных и гормональных препаратов для лечения спорадического и эндемического зоба. Результаты исследований представлены в докторской диссертации, защищенной в 1964 г. Научными консультантами этой диссертации были профессора В. Г. Вогралик и Б. В. Алешин.

Во время работы на кафедре терапии Горьковского мединститута А. С. Ефимов исследовал также патогенез и лечение нарушений сердечно-сосудистой системы при тиреотоксикозе и сахарном диабете (СД).

В 1965 г. А. С. Ефимов избран на конкурсную должность научного руководителя диабетологического отделения вновь организованного в Киеве НИИ эндокринологии и обмена веществ Минздрава УССР. С 1992 г. и до настоящего времени Андрей Семенович работает заместителем директора этого института по научной работе в клинике.

За время работы в НИИ эндокринологии и обмена веществ особенно ярко проявились незаурядные способности А. С. Ефимова как талантливого клинициста, вдумчивого ученого, энергичного организатора и администратора, пользуюшегося любовью и уважением младших коллег, преподавателя и вослитателя научных кадров.

Постоянная работа экспериментальных групп в составе руководимого А. С. Ефимовым отдела, а тахже сотрудничество с рядом институтов НАН Украины способствовали созданию надежной научно-экспериментальной основы для изучения патогенеза и разработки новых методов диагностики и лечения СД. Наиболее значимыми достижениями этих научных исследованй̆ признаны следующие: разработаны и внедрены в практику новые приборы, фармпрепараты; создана клиническая классификация СД и диабетических ангиопатий, предложены новые методы лечения. Из диагностических тестов описаны инверсия ответа ряда гормонов и метаболитов на нагрузку глюхозой у лиц с предиабетом. Создан и внедрен в лрактику экспресс-анализатор глюкозы "Глюкофот" с индикаторными полосками.

Изучение инсулинрецепторного взаимодействия выявило (в клинической практике и в ходе эксперимента) тормозящее действие на инсулиновые рецепторы всех основных контринсулиновых гормонов, а изучение инсулинрецепторного взаимодействия и внутриклеточных механизмов на культуре тканей позволило выделить подтипы СД I-го типа. В патогенезе ангиопатий впервые выяснена роль контринсулиновых гормонов, иммунных нарушений. Обоснование патогенетической роли гиперфункции полиолового пути обмена глюкозы позволило создать и внедрить в практику новый ангиопротектор "Изодибут" для лечения ангионейропатй̆, катаракты, энцефалопатий. Углубленное обследование участников ликвидации аварии на ЧАЭС и детей из загрязненных радионуклидами территорий показало "диабетогенный эффект" чернобыльских факторов, позволило определить механизмы формирования у этих контингентов гиперинсулинемии и/или инсулинорезистентности тканей. Из новых методов лечения СД предложены комплекс иммунокорректоров с ингибиторами протеолиза при СД l-го типа, трансплантация культуры $\beta$-клеток и криоконсервированной эмбриональной ткани печени, добавление к диете топинамбура, использование микроволновой резонансной терапии, лазерной терапии для лечения ангионейропатия.

Много времени и энергии А. С. Ефимов отдает учебно-педагогической деятельности. Его лекции, увлекательные по форме и доходчивые при изложении сложного материала, всегда собирают многочисленных слушателей. Следует также подчеркнуть дар А. С. Ефимова увлекать членов руководимых им коллективов научной работой, воодушевлять их на проведение непростого, а иногда и очень трудного научного поиска.

В 1985 г. А. С. Ефимов организовал кафедру эндокринологии в Киевском медицинском институте (ныне Национальный медицинский университет) им. А. А. Богомольца и до 1992 г. заведовал ею. В 1993 г. он организовал кафедру эндокринологии в Киевском институте усовершенствования врачей (ныне Начиональная медицинская академия последипломной Минздрава Украины, которой заведовал (по совместительству) до 2003 г.

А. С. Ефимов является постоянным и обязательным участником всех основных отечественных и международных научных и научно-практических мероприятий по эндокринологии съездов, конгрессов, симпозиумов, конферениий.

Весомый вклад А. С. Ефимова в развитие отечественной эндокринологии отмечен Государственной премией УССР в 1982 г. за участие в создании учебника "Внутренние болезни", орденом "Знак Почета" в 1984 г., званием заслуженный деятель науки и техники Украины в 1998 г., орденом "За заслуги III степени" в 2001 г., медалями.

А. С. Ефимов был избран член-корреспондентом АМН СССР в 1984 г., акалемиком АМН СССР в 1988 г., академиком НАН Украины в 1992 г. и академиком АМН Украины в 1993 г.

А. С. Ефимов всегда сочетал свою творческую работу с активной общественной деятельностью. В годы СССР он был председателем Киевского городского и областных обществ эндокринологов, членом правлений Всесоюзного и Украинского обществ эндокринологов, Украинского общества терапевтов, членом Научного совета по эндокринологии АМН СССР, экспертной комиссии по эндокринологии Минздрава СССР, членом ВАК СССР, редактором БМЭ. В настояшее время он является членом Европейской диабетической федерации (с 1990 г.), вице-президентом Украинской диабетической федерации (с 2000 г.), членом редколлегий журналов "Проблемы эндокринологии, "Ендокринологія" и "Endokrynologia"

Под руководством А. С. Ефимова выполнены 50 хандидатских и 15 докторских диссертаций. Он автор более свыше 600 научных работ, в том числе 28 монографий, 2 учебников, справочника, руководства, 30 патентов. Его ученики руководят клиниками, кафедрами, лабораториями.

Свой 80-летний юбилей Андрей Семенович встречает полным творческих сил, новых научных идей и замыслов. Его ученики, коллектив Института эндокринологии и обмена веществ им. В. П. Комиссаренко АМН Украины, эндокринологическая общественность страны горячо поздравляют дорогого юбиляра и желают ему доброго здоровья, неисчерпаемой энергии и воплощения всех его творческих планов.

Каллектив Ннститута эндокриналогии и обмена веществ им. В. П. Комиссаренко АМН Украинष

Редкаллегия журнала "Проблемы эндокринологии" присоединяется $\boldsymbol{x}$ поздравленияи. 